\title{
PARTICIPATORY ENVIRONMENTAL MANAGEMENT: GROUNDED THEORY PROPOSALS
}

\section{Mireya Palavecinos Tapia ${ }^{1}$; Daniel Henríquez Fernández ${ }^{2}$; Bartomeu Vidal Moranta ${ }^{3}$}

ABSTRACT: The environmental crisis and the growth of cities has made life in modern cities become more complex. The environmental management of the responsible institutions has been faced with generating new strategies and communicating with citizens to solve the environmental problems. This research describes the methodology used and the political dimension of citizen complaint behavior before the public administration. The results offer a more efficient management option that guarantees citizen participation as a quality strategy and considers their proposals for the solution of urban environmental problems. The mixed method is used, and the analysis of the data is based on the Grounded Theory to know the reality and the difficulties of the people involved, considering their interpretations, having as object of investigation the perception about the environmental conflicts. The research was structured in stages and successive phases, interviews and surveys were carried out with experts. Analyzed complaints ( 532 suggestion and complaint files, for situations of urban environmental conflicts). Group interviews with neighbors, representatives of social movements, officials and students of a University. Finally, virtual surveys and individual interviews with group participants were conducted. The results allow to describe and propose a Participatory Environmental Management Model, which considers as criteria for effectiveness, the validation of the role of people in the solution to problems, allowing to implement solutions more relevant to local needs and to solve urban environmental conflicts in public management.

KEYWORDS: participatory environmental management; citizen complaint; grounded theory.

RESUMO: Ante a crise ambiental e o crescimento das cidades, a vida moderna tornou-se mais complexa. Gestão ambiental das instituições responsáveis viu-se enfrentada a gerar novas estratégias e comunicar com a cidadania para solucionar os problemas ambientais que enfrentam a diário. Descreve-se a metodologia utilizada e a dimensão política do comportamento de denúncia cidadã ante a administração pública. Os resultados oferecem uma opção de gestão mais eficiente, que garanta a participação cidadã como estratégia de qualidade econsidere suas propostas paraa solução dos problemas ambientais urbanos. Recorre-se ao método misto, e fundamenta-se a análise dos dados na Teoria Fundamentada para conhecer a realidade e as dificuldades das pessoas envolvidas, considerando suas interpretações, tendo como objeto de investigação a percepção sobre os conflitos ambientais. A investigação estruturou-se em etapas e fases sucessivas, realizaram-se entrevistas e pesquisas de especialistas. Analisaram-se denúncias apresentadas ao município (532 fichas de sugestões e reclamações, por situações de conflitos ambientais urbanos). Entrevistas grupais a vizinhos, representantes de movimentos sociais, servidores públicos e estudantes de uma Universidade. Finalmente foram realizadas pesquisas virtuais e entrevistas individuais a participantes dos grupos. Os resultados permitem descrever e propor um Modelo de Gestão Ambiental Participativa, que considere como critérios para a efetividade, a validação do papel das pessoas na solução aos problemas, permitindo implementar soluções mais pertinentes às necessidades locais e resolver os conflitos ambientais urbanos no gerenciamento público.

PALAVRAS-CHAVE: gestão ambiental participativa; denúncias cidadãs; teoria fundamentada.

RESUMEN: Ante la crisis ambiental y el crecimiento de las urbes, la vida en ciudades modernas se ha complejizado. La gestión ambiental de las instituciones responsables se havisto enfrentada a generar nuevas estrategias y comunicarse con la ciudadanía para solucionar los problemas ambientales que enfrentan a diario. Se describe la metodología utilizada y la dimensión política del comportamiento de denuncia ciudadana ante la administración pública. Los resultados ofrecen una opción de gestión más eficiente, que garantice la participación ciudadana como estrategia de calidad y considere sus propuestas para la solución de los problemas ambientales urbanos. Se recurre al método mixto, y se fundamenta el análisis de los datos en la Teoría Fundamentada para conocer la realidad y las dificultades de las personas involucradas, considerando sus interpretaciones, teniendo como objeto de investigación la percepción sobre los conflictos ambientales. La investigación se estructuró en etapas y fases sucesivas, se realizaron entrevistas y encuestas a expertos. Se analizaron denuncias presentadas al municipio (532 fichas de sugerencias y reclamaciones, por situaciones de conflictos ambientales urbanos). Entrevistas grupales a vecinos, representantes de movimientos sociales, funcionarios y estudiantes de una Universidad. Finalmente fueron realizadas encuestas virtuales y entrevistas individuales a participantes de los grupos. Los resultados permiten describir y proponer un Modelo de Gestión Ambiental Participativa, que considere como criterios para la efectividad, la validación del rol de las personas en la solución a los problemas, permitiendo implementar soluciones más pertinentes a las necesidades locales y resolver los conflictos ambientales urbanos en la gestión pública.

PALABRAS-CLAVE: gestión ambiental participativa; denuncia ciudadana; teoría fundamentada.

Mireya Palavecinos Tapia. Phd. Social Psychology, Autonoma University, Madrid, Spain Filiation; Associate Professor at the Department of Psychology. Director of the Master in Community Psychology. University of La Frontera, Temuco, Chile. Postal address: Montevideo \#83o, Temuco, Chile. Email: mireya.palavecinos@ ufrontera.cl

2 Daniel Henríquez Fernández. Master in Community Psychology. University of La Frontera. Filiation. Lecturer at the Department of Psychology, University of La Frontera, Temuco, Chile. Postal address: Montevideo \#83o, Temuco, Chile. Email: daniel.henriquez@ufrontera.c

3 Bartomeu Vidal Moranta. Phd Social Psychologist, Barcelona University, Spain. Filiation Professor at the Faculty of Psychology, University of Barcelona, Catalonia, Spain.Email: tvidal@ub.edu 


\section{INTRODUCTION}

Institutions in charge of city administration, such as municipalities, have sought for structures which guarantee quality management and performing greater control over its administration mechanisms. To guarantee the needed transparency and governance, these institutions are searching for considering citizen participation in the process, by receiving complaints or grievances, thus creating technical instances for on-the-field interventions and looking for support at universities for researching these issues. The present study is an example of this link.

The creation of systems for issuing complaints and their proper reception has been one of the measures requested to modern administration to guarantee citizens spaces for relationship and trust, as well as governance. However, this has only been actively incorporated to public administration very recently.

One of the spaces recently created has been considering the opinion of people, mostly on how resources are administered and on how environmental conflicts are solved within cities. It is a relatively new process which has important aspects to be developed.

One of the most common problems is the confusion regarding handling data and the opportunities offered by the data obtained after communication with citizens. They do not know how this information contributes to the processes of institutional management. Most of the time, the information provided by people to the public administration is not properly used or is undervalued by organizations, therefore the contribution they can offer as feedback for improving the quality of management is wasted. The solutions still do not consider the citizens' insights, and they are based exclusively on technical decisions or on political reasoning, so they risk not being adequate or relevant. Because of this, problems linger, expenses increase, and distrust from people towards central administration and the responsible political authorities keeps increasing. Citizens consider that their needs are not being considered, and what is worse, they verify day by day that environmental problems persist or even aggravate. At the administration level, managers eventually end up implementing interventions and technical decisions that are not relevant or properly allocated. (Palavecinos, Martin, Díaz, Piñeiro, Benayas, y Alonso, 2008).

The study of the complaint as a specific behavior, and particularly citizen complaints regarding environmental issues, seems to be an interesting gateway to understanding this emerging phenomenon. Defining the boundaries for the research problem for this study, meant a long journey, starting from the existence of a real problem: the meagre results obtained in solving the environmental problems of a capital city in Spain, despite the increasing economic investment that the municipality has made to address the problems derived from poor environmental management in the city (such as mass education campaigns, high investment in infrastructure and resources).

In this context, the City Council contacted the Department of Ecology of a local University, as a result of this, an agreement was signed to carry out research aiming to understand the situation in the city and the social phenomenon of increasing complaints, and also to generate proposals for improving environmental management results.

The following research objectives were stablished: a) To build a comprehensive model of citizen complaints regarding environmental issues, identifying the meaning people give to the presentation of their complaints, b) To achieve the detection of entanglement in the environmental management process and c) To evaluate the management system used by the municipality, and then propose an administration model that improved efficiency in municipal management for solving existing urban conflicts.

\section{THEORETICAL BACKGROUND}

People seek to enjoy their capacity to achieve satisfaction and comfort in the environments they occupy. According to Daniel Stokols, the environment is an end in itself, it is the context in which the human beings develop and fulfil themselves. In this vision, symbolic, affective, psychological, social and cultural meanings are emphasized and awareness, also promoting participation and cohesion of human beings occupying their spaces (Stokols, I990).

Along the same line, the socio-constructionist conception postulates that the meanings of the environment are elaborated under certain political, 
economic and social contexts that eventually define the considerations, conceptions and uses of the environment by the users (Wiesenfeld, 200I).

From a number of perspectives, beliefs have taken a decisive role in understanding the relationship between human beings and the environment. In fact, the ongoing problem of growing ecological and social deterioration has been attributed to certain generalized assumptions in keeping with «what the world is like» (Clark, 1995; Milbrath, 1995, White, 1967).

Milbrath (I995) postulates that modern industrial societies are not sustainable, since social thinking is based on premises or beliefs based on human progress at the expense of nature's domain. The relationship between human beings and the environment is determined by beliefs regarding their own nature, the physical world, their own fate and "what we do in terms of ecology depends on our ideas about the relationship with Nature" (White, I974, p. 26).

I order to achieve the objectives set for this research, it has been considered important to use a mixed research method which allows for establishing trends and quantitative data in the diagnosis of the situation, but at the same time giving strength to the voice of those involved in urban environmental conflicts. Thus, giving a fundamental role to the needs expressed by the citizens who endure the problems in order to know the reality that affects them, is considered a necessary starting point to build efficient technical solutions, which are also relevant and pertinent to the local reality.

From the theoretical point of view, four constructs related to the case under study will be addressed. These constructs are essential for understanding the dimensions considered by the study: Pro-Environmental Behavior, Complaint Behavior, Participation (social and environmental) and Environmental Governance.

2.I PRO-ENVIRONMENTAL BEHAVIOR (CER)

It can be defined as the action carried out by a person, individually or collectively, in favor of the conservation of natural resources and aiming at procuring better quality for the environment. Sustainable development and sustainable behavior are linked to the idea of motivated and intentional behavior (Brundtland Report, UN 1987).

This behavior has also been defined by its impact, the degree in which it is able to change the availability of the environment's materials or energy, or to alter the structure and dynamics of the ecosystem or biosphere. From the actors' point of view, it is considered as a committed behavior or with the intention of changing (benefiting) the environment (Hernández, and Suárez, 2006, Stern, 2000; Stern, 200ob; Stern and Gardner, 1996). It must be taken into account that there are several barriers (mainly contextual factors) which might constrain or stimulate the development of pro-environmental actions (Gardner and Stern, I996; Tanner, 1999; Stern, 200ob).

Figure 1. MASEM results.

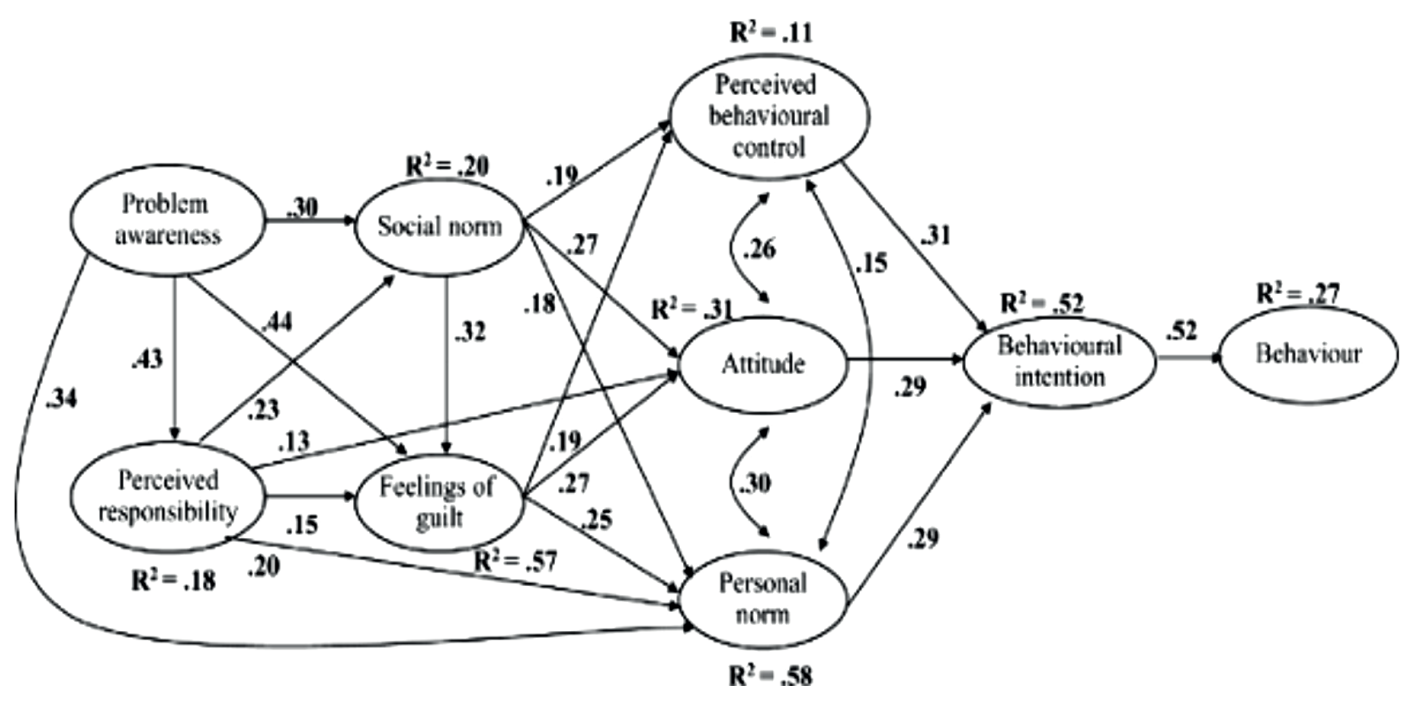

Source: Bamberg and Mosêr, 2007. 
Bamberg and Möser (2007) carried out a new review of determining factors mentioned in scientific literature. Among the results of this macro comparative study, it can be highlighted that there are significant correlations between psychosocial variables and pro-environmental behavior, which are similar to the ones reported by Hines, et al., 1987. These correlations confirm that the variable Intention of pro-environmental behavior mediates the impact of all other psychosocial variables (accounting for $27 \%$ of the variance). The results also confirm that after Attitude and Behavioral Control, Personal Moral Norms are the third predictor of Intention of pro-environmental behavior (accounting for $52 \%$ of the variance).

\subsection{COMPLAINT BEHAVIOR (CB)}

There are psychological-cultural barriers in our society that are preventing us from developing sustainable behavior, thus destructive behaviors are sustained and become resistant to change. Despite this, peopless concern for their environment's situation can be seen, for example, in the large number of complaints filed at their municipality regarding environmental problems in the city. How can this be explained? Developing an understanding of the characteristics of the particular situation and the sense people give to their behavior of complaints in environmental matters is the main objective of the present investigation.

There is agreement among scientists in understanding The Complaint as the result of an experience defined as unsatisfactory by consumers. No studies were found that compare the presentation of complaints to public institutions and the differences that this could have with those presented to private organizations. Most authors tend to provide definitions that reflect the multidimensional nature of complaint behavior, which is not only limited to the sole act of complaint, but also covers other responses to dissatisfaction after a purchase (Singh, 1990a; Singh and Wilkes, 1996; Liu and McClure, 200I).

Singh and Wilkes (I99I) propose a definition in which a customer complaint includes all the possible behavioral responses a client might use to address their dissatisfaction. Singh (I990a) identifies complaint behavior as the style of response from a dissatisfied customer. Crie (2003) defines the customerss complaint behavior as a process that constitutes a subset of all possible responses to dissatisfaction perceived around a purchase episode, either during consumption or possession of the goods or services. Crie also states that a complaint behavior is not an instant response, but a process that does not depend directly on its initial factors, albeit on an evaluation of the situation by the client, and further evaluation over a period of time.

The public complaint refers to actions of direct complaints, which include the search for direct reparation by the supplier or manufacturer, as well as legal action (Bearden 1983; Bearden \& Oliver 1985; Cornwell, Bligh, and Babakus 1991). Public actions a person may carry out include verbal complaint, written complaint or letters of complaints sent to newspapers, or complaints handled by consumer advocates (Heung \& Lam 2003). Thus, public complaint behavior is a set of communications initiated by the consumer towards the manufacturer, intermediaries or public institutions, in order to solve problems arising from a purchase or the use of a product in a certain transaction (Westbrook, 1987).

The available evidence indicates that only a small percentage of unsatisfied clients actually complain and that the demographic and psychological characteristics of the clients themselves play an important role in determining their response (McAlister and Erffmeyer 2003; Lovelock and Wirtz 2007; Zeithaml, Bitner and Gremler , 2006). The influence of cultural differences on complaining customers' behavior has been examined and yield conflicting data (Liu et al 200r; Mattila 1999; Mattila and Patterson 2004; Zeithaml et al 2006). A study conducted by the Ecological Institute of Berlin (20I2) describes four types of complaint behavior:

Private actions. Public institutions are not involved. Complaints are commented among families and friends after a poorly evaluated purchase or service. In general, it is decided not to use the service any more or not to buy the product again. The complaint might be directed to the seller verbally.

Legal actions. A legal approach is considered to remedy the action: complaints are filed with public agencies, senators, defenders of the people or payments to the companies involved are stopped.

Public actions. Complaints are filed with the companies involved in order to find a solution. It involves confrontation and the request for a 
return or product repair, file complaints with consumer agencies or writing to newspapers.

No complaints. No action is taken after the bad experience.

As already mentioned, complaint behavior (CB) might be influenced by multiple factors, among which market structure, socioeconomic variables, involvement and probability of success, are highlighted as the most studied and significant. Whether or not the socioeconomic situation of consumers can condition this behavior has also been studied (Moyer, I984).

In different studies carried out in Spain, Moliner (2004, 2007, 2008) proposed to classify the determinants responsible for complaint behavior in the context of consumption, in order to identify the variables that have been investigated most frequently and offer a wider vision regarding the formation of complaint behavior. This classification groups the determinants into four types: a) Determinants that refer to the characteristics of the consumer (general and specific to the unsatisfactory experience). b) Determinants related to the company providing the product or service causing the dissatisfaction. c) Determinants relative to the environment in which the purchase and/or delivery of service happens. d) Determinants that are intrinsic to the product or service provided (Moliner, 2007).

There are occasions in which the procedures established for the reception, processing and resolution of the complaint cause the customers more inconvenience than the failure itself. Conducting an effective process of handling complaints in organizations can constitute a differentiation criterion for companies and opens the possibility of permanent feedback relative to customer satisfaction. (Moreno Pino, et al, 2009).

According to Broadbridge and Marshall (I995), the complaint helps companies identify the determinants of the quality of their offer, thus making the appropriate improvements in their processes (Fornell and Wernerfelt, I987). Public actions allow consumers to accumulate information about the problems and defects of the products and services offered. Besides, it also provides the product or service provider a second chance to satisfy the consumer. Complaints are also considered as useful tools to make strategic and operational decisions. Therefore, the complaint represents the origin of the solution of the problems and the possibility of retaining the customer. The absence of complaint removes any possibility of eliminating the source of dissatisfaction. Finally, if the complaint is satisfactorily resolved for the consumer, this will influence the improvement of the companys image (Richins, I983a). Satisfaction after the resolution of the complaint has been studied in different empirical investigations aiming to demonstrate the importance of motivating individuals to present their complaints, as well as the way they are subsequently addressed. (Oliver, I987).

Environmental complaints have not yet had significant presence in scientific studies, and they have recently been included as a concern in public administration. One mechanism is the one put forth by the European Environment Commission (DG), in which stages for a typical procedure are proposed for the analysis of complaints; Awareness - Acknowledging complaints. Evaluating the complaints received and prioritize them. Planning research on these topics. Investigating complaints. Answering them with a clear decision. Following up on services. Considering whether they constitute systemic problems.

\subsection{SOCIAL PARTICIPATION}

Participation may take various forms depending on the characteristics and objectives of institutional interventions. The "citizen participation" label summarizes the basic principle of co-responsibility and multilateral commitment by institutional agents, citizens, technicians and interest groups, which constitutes the basis of a democratic project (Bonet, Di Masso, Duque, Ëcija, Pol, 2006).

Participation is a process through which communities intervene in their reality by organizing and setting priorities according to their needs in order to achieve improvements in quality of life and general well-being. It aims to improve the possibilities of access to goods and services. It allows for integration to ongoing processes in a society. It improves the opportunities to fulfil a life project, to make citizens feel as protagonists deliberately building a future and, ultimately, to strengthen their self-esteem. At present, the most interesting participation processes are those designed to broaden consultation, processes in which an attempt is made to achieve greater citizen involvement and in which decision-making based on experts' technical 
criteria, rational decision, and citizens' preferences are combined (Pont Vidal, 2004).

In participation processes, communication is materialized in proposals and action programs that distribute knowledge, objectives, means and specific responsibilities among all the participants. These proposals can be classified around three basic criteria:
a) Degree of involvement of the different social agents (level of demand for attention, effort and involvement)
b) Degree in which power and responsibility are granted.
c) Level at which the different social agents have the capacity to get involved in evaluation and decision processes.

In the case of the opening of channels for the citizen to express complaints to situations they detect in the managed urban space by public institutions, it is possible they risk these channels remain in the system without greater possibility of incidence for the administration of solutions to the problems. If so, we would face the lowest profile of the three criteria; that is, low involvement of social agents, low empowerment, and poor capacity to get involved in decision-making processes.

To achieve efficiency in the intervention in environmental problems, this intervention must be based on knowledge of the local psychosocial processes linked to the environmental problem. To this end, novel forms and channels of communication that encourage citizens to participate must be strengthened and created, overcoming the sole mediation of representatives in organizations. Participation must be seen as a planned process, aiming towards transformation, capable of giving new value to the power of citizens and pointing to the development of the reflective capacity in political decision making (empowerment), thus improving the quality of democracies (Bonet et al., 2006).

Other types of participation proposed and linked to the subject of research are: Participation in decision-making and social control of assumed public commitments. It refers to the intervention by community agents (individuals, community groups) in decision-making processes, as well as in the formulation of public policies, in their designs and programs, and in the supervision and control that may be enforced by the community. This element implies exercising citizen rights, the 494 and to complain, the right to appeal and challenge decisions by the authority, to confront ideas, to reach consensus and to decide; The Participation Associated to the Execution and Management of Programs refers to the assessment of participation as an instrument that contributes to improve the quality of the Governmentss social action. It aims to stimulate, favor, and promote, in different degrees and levels, the direct participation of the beneficiary population in the administration of social programs and projects.

Environmental Participation is a particular form of citizen expression which describes the set of behaviors that aim to influence decision-making in regard to some aspect associated to the environment, especially referring to its conservation, protection and quality. It reflects the proposals for collective action by environmental activism.

In contrast to the models developed from political psychology, psychoenvironmental research has approached the study of the participation process in relation to the environment and nature from perspectives that aim for the evaluation of the effect of environmental contents on participatory behavior. It is about analyzing the effect the ecological situation or, more specifically, its social interpretation, has on participation (Suarez, 1996).

Environmental participation is characterized as a set of action forms coming from the existence of organized patterns of collective activity, both intentional and functionally instrumental, whose objectives are associated with some kind of social change and that contribute to the achievement of collective benefit (Khan, 1999). Therefore, under the umbrella term of environmental participation, these actions are grouped among different behaviors, which respond to different degrees of involvement in collective actions.

Environmentalism and activism around conditions, changes, defense and protection of the environment and nature stand out essentially as some of the most characteristic examples of what is understood by new social movements. Regarding the kind of behaviors grouped under the topic of pro-environmental participation, they range from voting to green parties, attendance to rallies and / or participations, participation in boycotts, signing of petitions, participating in public debates, writing opinion articles, or providing economic support. All of them imply an effort to change the attitudes and actions held by policy makers and citizens in 
relation to the conditions of threats to environmental quality (Manzo and Weinstein, 1987).

Environmental participation can also be understood as a specific form of social responsibility execution regarding environment and nature. It differs from other pro-environmental actions due to the collective dimension that defines it. Activism or militancy constitutes the second notion related to participation.

Environmental participation has been perceived from a double perspective. On the one hand, as a result of the reaction to environmental conditions to which people are exposed. On the other, as a product of the general system of attitudes and beliefs still remaining regarding the environment.

\subsection{GOVERNANCE}

What are the contributions and challenges of environmental governance? What is the role of deliberation in building consensus? The concept of governance is approached from the political point of view, in which consensual decision making becomes the center of analysis.

The notion of governance was born in the years of intense globalization, as a way out of a series of phenomena worldwide such as environmental degradation, nuclear danger, economic crises together with high unemployment, the rise of terrorism and organized crime. This new construction of the concept of governance allows us to take the different conflicts of societies in risk to the search for concrete and specific solutions, marked by the scales of action and the commitments made by the different actors (Alfie et al., 2ori).

In recent years, the three pillars of the contemporary modern state have been directly affected: security, governance and sovereignty. At the same time, the socio-economic changes and transformations of the last twenty years have given rise to the consolidation of non-governmental organizations (NGOs), international organizations (IO) and multinational corporations (MC) as important actors within the political scene (Alli Aranguren, 2013).

Some theorists forecast the imminent loss of political power by the State as an irremediable fact. Its role as an intermediary in political, economic and social processes is diminished due to its loss of influence in decision making and control over investment flows, territorial re-location of the actual factors relatives to production of goods and services (by regions or cities and not countries), and the intensive use of information technologies (Ohmae, I995). In essence, the State has changed and, as part of this transformation, public and private agencies have become part of a broad network of multi-level regulation, gaining ground against a more traditional State-centered conception (Beck, I998).

In this context, the term of governance emerged some years ago as opposed to a vertical vision in the decision-making process that used to fundamentally present the nation-state as the sole actor. Etymologically, the word governance comes from the Greek kubernan (leading or guiding) and was used by Plato when referring to a system of rules to govern.

The concept has been used as a synonym for government, but also as the act or the way of governing, or the government function itself. Beginning in the I980s, Political Science scholars gave a broader connotation to the use of the term governance, by incorporating civil society into the concept as an actor of great relevance in decision-making and, therefore, an engine for the transformations experienced within the relationship between society and the State (Alfie, Cohen,, Díaz and Castañeda, 20II).

Governance, in general terms, is part of stablishing channels for communication between the government and civil society, both for dialogue and joint action in agreement, exercised autonomously and differently from the traditional mechanisms of aggregation, corporatization and participation within political parties and the state in general. Governance refers to a fluid, transparent, flexible, participatory and creative administration, in which there are anonymous, silent and minority groups spread across multiple levels and contexts to participate in decisions that are relevant to them. In this governance, new collective practices based on negotiation and consensus, together with citizen networks of flows and interactions that operate along with the State in the decision-making process are registered.

The contributions of Aguilar Villanueva stand out in the field of public administration research. This author considers that the creation of a "new public administration" and / or the "new governance" allows, on the one hand, the balance of fiscal and administrative malformations of 
governments and, on the other, permits a greater capacity for governmental response to the social and economic transformations that contemporary societies experience. This conception of administration in charge of the State, seeks the promotion of the public exercise legitimacy through democratic and socially inclusive practices in the construction of consensus for the resolution of specific conflicts (Aguilar Villanueva, 2006).

Governments today must prove their ability to provide public services with efficiency and quality, while at the same time solving the society's problems and rebuilding the social trust that has suffered significant erosion in general. In order to achieve this, modernization and innovation within the public administration is urgent, both in its organization and in its management and operation. (Aguilar Villanueva, 2006).

Although it is certain that the phenomenon of governance has led to the reformulation of public administration when trying to provide efficiency in governmental tasks, it can also be seen how governance, in the field of politics, falls within the orbit of the Deliberative Democracy (DDF). (Bäckstrand et. al., 20Io).

Regarding environmental crisis, the results of international environmental administration have been insufficient in the face of the accelerated rhythm of environmental degradation on the planet. Some indicators even reveal that the general environmental situation has deteriorated, despite the signing of international agreements on the subject.

Part of the explanation for this problem can be found in the institutional and structural inefficiency of the United Nations Environment Program (UNEP), as well as in the low budget allocated to fight deterioration, the ineffectiveness of intergovernmental mechanisms and non-binding nature in the enforcing of norms, conventions, treaties and protocols. This has prevented assigning clear and concrete responsibilities for environmental risk. Other scholars consider that the key to this failure is found in the existence of more than 500 multilateral environmental agreements, since they overlap, are dispersed and even conflict with each other, undermining opportunities to carry out effective coordinated actions (BierMann and Benhüneryanna, 2009).

For James Meadowcroft (I996), the notion of deliberative democracy in Environmental Governance can significantly improve the ability of the society to address the problems of the coming decades. Politicians should take into account a variety of dynamics between natural resources, market and social conditions as these decisions will require broad support, a boost to joint learning and the extension of interactions both collaborative and deliberative based on groups that bring together stakeholders, the government, companies and civil society.

The exercise of environmental governance is based on intersectoral collaboration as a tool to reconnect citizens with the construction of a common purpose and the improvement of decision-making processes. The construction of civic environmentalism based on environmental protection, with bottom-up actions and approaches in which the territory takes a key role. The collaborative administration of natural resources and ecosystem management is sought in order to adapt solutions to local conditions and overcome bureaucratic fragmentation (Meadowcroft, I996).

Environmental governance will have to implement available social resources for its good performance. Some of these resources are: the participation of agents committed to the situation at hand, the use of clear language, the promotion of intersectoral relations with a common purpose, decentralization and the implementation of justice and environmental equity as a core value.

\section{METHOD}

The research is framed within the qualitative paradigm, which according to Rey (2000) is based on three epistemological principles: a) understanding knowledge as a constructive-interpretive production, in which the role of the researcher is to integrate, make sense, rebuild and present a complex set of facts in complex categories, b) assuming the interpretation as a process of progressive complexity, which is developed through the significance of various forms of what is studied, c) its interactive nature in the production of knowledge as long as the researcher interacts dynamically with the subjects. Therefore, it is an inductive method that addresses human flexibility from the context of the development of events. Scientific knowledge thus understood is not legitimized by the number of subjects, but by the quality of its expression according to the need for the discovery process that is being generated during the ongoing investigation (Rey, 2000). 
Consistent with the qualitative aspect, it is important to highlight participation as a central axis of the construction of knowledge. Geilfus (I997) points out that the participants should be considered not only as sources of information, but as co-researchers who contribute in decision-making, analysis and the proposal of solution through joint actions. In a review carried out by Rivadeneira (2015) some epistemological principles are rescued, given to the research by the participatory dimension: a) consideration of different perspectives, b) consideration of the reality of the members of the process, c) contextualization of the historical dimension, d) construction of theory from practice, e) popular participation, f) political commitment of the researcher, g) recognition of the political and ideological nature of the scientific undertaking, h) conversion of research, education and action into methodological moments of a single process for social transformation. Therefore, accepting this notion of an intersubjective co-construction of reality (Schutz, 2003) implies refuting the critical objectivism demanded by positivist science, since the subject-object dichotomy becomes indefensible (Crotty, 2003).

For this case study, the Grounded Theory was used as a guide for the process in general, since this tradition is characterized by inductive procedures that facilitate an approach to the daily life of subjects through their own interpretations, having as an object of investigation human action (Merleau-Ponty, I962). For the data analysis, an open, axial and selective coding is used, resulting in a set of conceptual categories that operate as translations of the subjects> experience. Grounded theory finds its basis in symbolic interactionism (Blumer, I969), whereas understanding (Verstehen) of intersubjectively constructed meanings overlaps causal explanation (Erklären), therefore, building interpretations based on the subjects' narratives is sought, having human action as their object of investigation. From this perspective, it is suggested that we are the result of our relations in and with the world (Merleau-Ponty, I962).

A single case design was chosen, therefore its analysis is focused on one case and its use in this particular case is justified as it has a critical nature, which allows for confirming, modifying or expanding the knowledge about the study ( Yin, I984), expanding knowledge and theoretical construction (Stake, 2005; Yin, I984). The case under study is limited to the manifestation of complaints from citizens, in the experience of environmental conflicts presented to the public institution. This design seems to be the most suitable for its approach in accordance with the reality observed and the general objective of contributing with theoretical knowledge in a social phenomenon that, to this date, has been scarcely studied.

\section{I PROCEDURE}

During the investigation, it was sought to favor and increase participation from different levels of involvement in the case, in order to achieve this, the collected data was triangulated and problematized in different instances with the participants, applying techniques of different origin or nature, thus obtaining different type of data of from various actors and perspectives. The three stages that shape the study and the objectives in Figure 2 are described below. In Figure 3, the participants, procedure and analysis techniques used for each of them are described.

Achieving the objectives required the collection of different types of data and the selection of multiple sources of information organized in specific forms of analysis forms for each type of data, in the three stages set for the investigation.

\section{RESULTS}

The data will be presented as they appear in each of the three stages of the study.

\section{Stage I. Delphi Groups with Experts.}

The results yielded by the Delphi group with I7 experts in the different central themes of the study (individual interviews, surveys and group discussion) allow us to reach the following proposal: the behaviors of complaint, pro-environmental and social participation are linked to each other. Sustainable behavior would include all three types of behavior, since it includes pro-ecological actions (or care for the environment) and acts of care for the social environment. Therefore, it includes social participation.

For this group of experts, there would be a deep link between environmental complaint behavior with responsible citizen behavior, the notion of citizenship and especially the concept of active citizenship, since it is required that individuals and groups are empowered, proactive and 
Figure 2. Stages and objectives of the study.

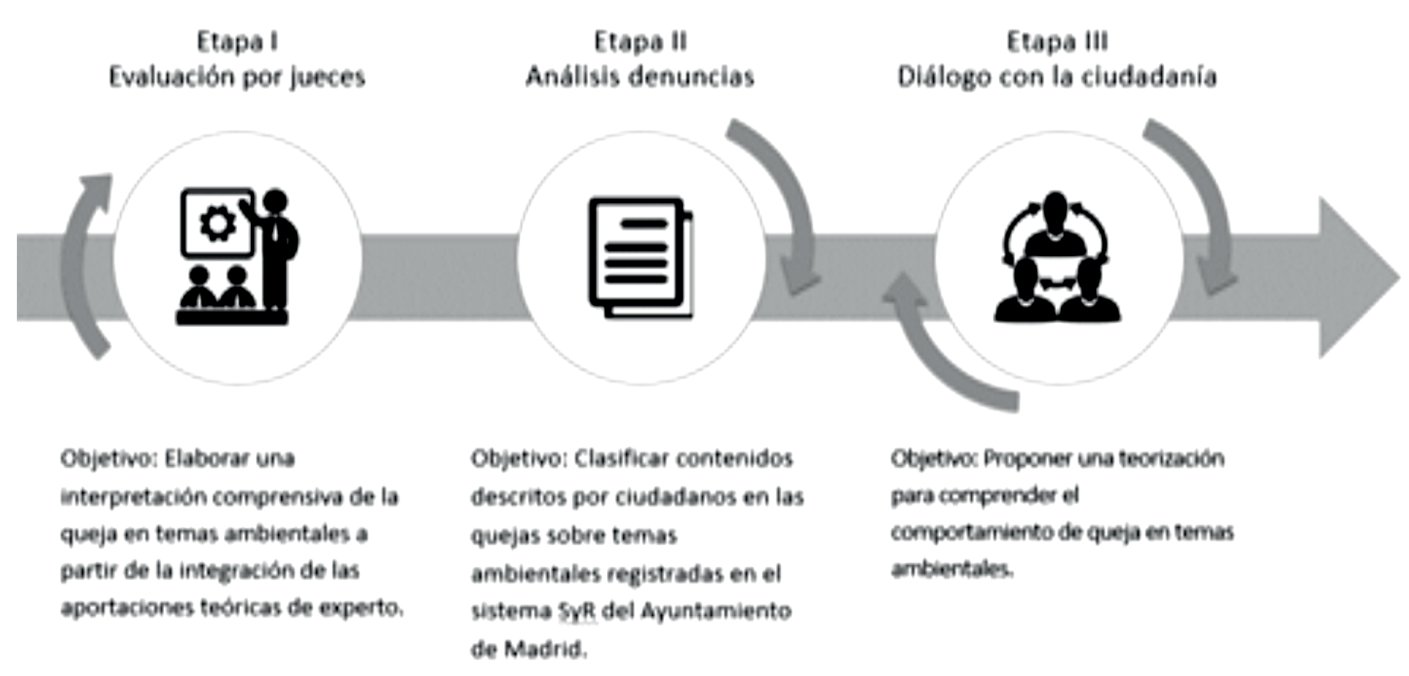

Source: Prepared by the authors.

Stage I. Arbiter Evaluation. Objective: To elaborate a comprehensive interpretation of the environmental issue complaint from the integration of the theoretical input by experts.

Stage II. Analysis of Complaints. Objective: To classify the contents described by citizens in environmental issue complaints filed within the SyR system of city council.

Stage III. Dialog with citizens. Objective: To propose a theorization in order to understand complaint behavior in environmental issues.

Figure 3. Types of data and analysis according to stages of the research.

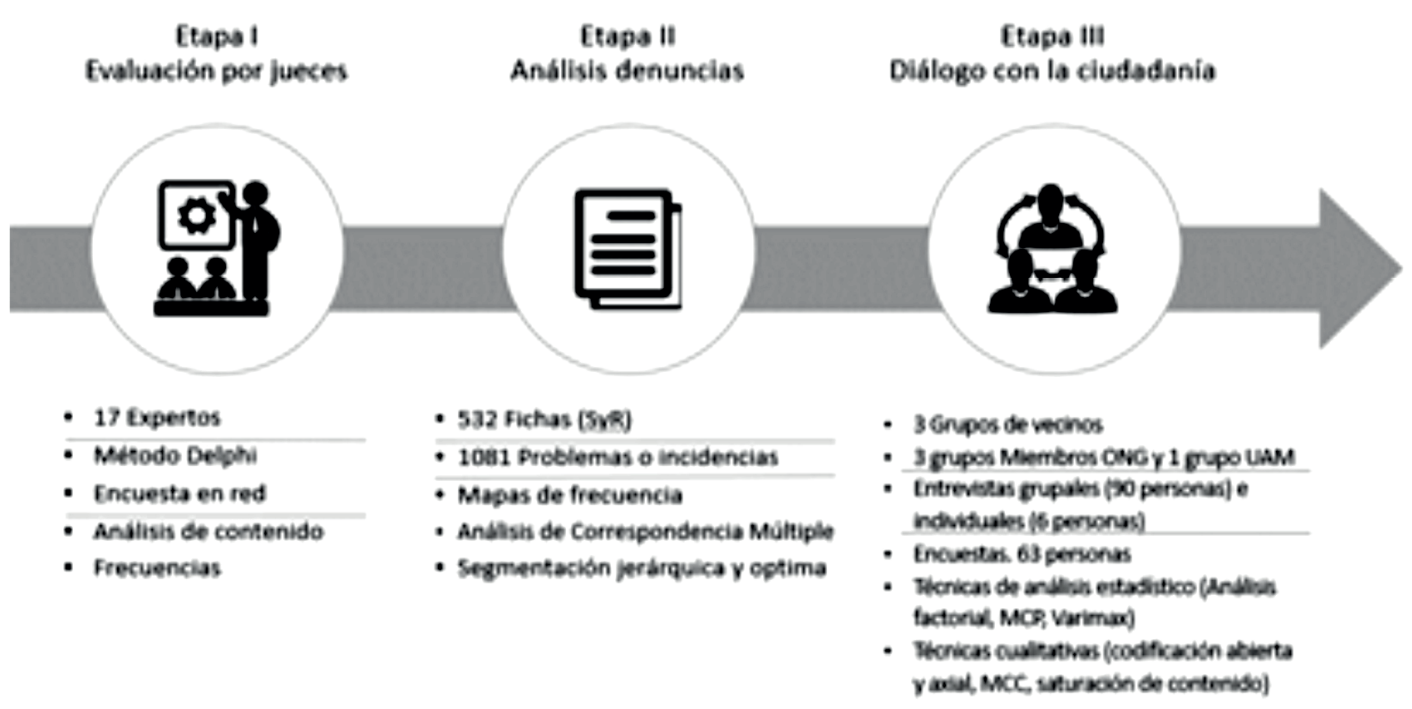

Source: Prepared by the authors.

Stage I. Arbiter Evaluation. i7 Experts. Delphi method. Online survey. Content análisis. Frequencies

Stage II. Analysis of Complaints.532 files (SyR).Io8I problems or incidents. Frequency maps

Analysis of multiple correspondence, Hierarchical and optimal segmentation

Stage III. Dialog with citizens. 3 groups of neighbors.3 groups members of ONG and I group UAM. Group interview (9o people) and individuals (6 people). Surveys (63 people). Statistical analysis techniques (factorial analysis, MCP, Varimax). Qualitative techniques (open and axial coding, MCC, content saturation) 
having the feeling that with their actions they can effectively achieve the desired changes.

The complaint is then described on environmental issues as a vindicating and participatory behavior, either collective or individual, specific or situational (depending on the type of problem). It is a finalist action (aiming at achieving something for someone) and externally motivated, seeking to put on the public agenda those issues related to the preservation of the environment. They are vindicating activities, justified in defense of what are considered rights. It is an action of individual and / or collective protest for a process that has a negative impact. Its purpose is to show opposition and / or rejection to other peopless behavior or decisions taken at different levels which are perceived as harmful to the environment (Delphi Group of the study).

In summary, for the experts consulted, the environmental complaint would be another pro-environmental behavior, a behavior for the provision of information, vindication and action, aiming at modifying the way in which resources are administered in relation to their impact on the environment. In this sense, it can be considered a virtual or direct behavior, product of a visual impact or the perception of insecurity which, for its manifestation, requires strategies that address the complaint appropriately. Confidence in the process and in the capacity to respond; knowledge of the procedure to file the complaint; having social support; the perception of justice or equality; toghether with awareness and concern for the environment can be mention as necessary conditions. The environmental complaint is a behavior that arises from the non-confirmation of expectations. It depends on some demographic and psychographic characteristics related to the individual, and also the level of information and interest in politics they have.

Stage 2. Analysis of the system for filing complaints and claims (SyR files).

Ensuring the premise of citizen participation in the study, another of the data sources used in the corpus of this research were the Suggestions and Claims Sheets (SyR) the institution makes available to people to file complaints regarding situations of urban environmental conflict affecting them. In this case, 532 selected files were analyzed (when reaching the defined criteria presented in the last three months, all the data completed, and cases defined as closed by the administration of the institution).

Unlike what was previously believed by the agents, the records show that the people who complained were men and women distributed in similar quantities and residing in the different districts or neighborhoods of the city. They preferably used the telephone or internet to file the complaint. The departments of Cleaning and Waste management are mainly involved, which happened in very similar proportions.

The most reported problems are related to the perception of a poor environmental administration due to the delivery of services with a lower quality than expected, particularly in relation to problems of cleaning and waste collection in the city. The most recurring complaints have to do with the frequency and the established schedules for the collection of waste, the amount of infrastructure available for this work, and the way in which public space is used for the installation of infrastructure that takes away room originally intended for other purposes.

A very important meaning is assigned to the public space. Great value is already given for social gatherings, recreation and leisure, all of which would be negatively affected by the type of administration according to the perception of citizens. Special importance is given by people to the places> appearance, a value assigned to the aesthetics of places, an impact that becomes a complaint when it is negative.

In relation to the impact of environmental problems, claims are usually presented for the inconvenience caused by the situation for the community as a whole, rather than for the perceived consequences at the individual or personal level. The departments responsible for the management deliver responses to complaints in only $20 \%$ of the cases, thus, only a very small percentage of them is actually receiving an effective solution.

The environmental conflicts expressed by the citizens in the registration instrument (SyR) after the classification allowed for the identification of a total of I,O8I problems. For the analysis, categories were formulated for its description, definition of the variables and related values. The information was then transferred to a database on SPSS for quantitative analysis. The complaints were finally categorized in the following labels: complaint matter, type of environmental conflict identified, responsibility assigned to the problem, 
Figure 4. Characterization of the complaint. Profiles of citizens filing the complaints.

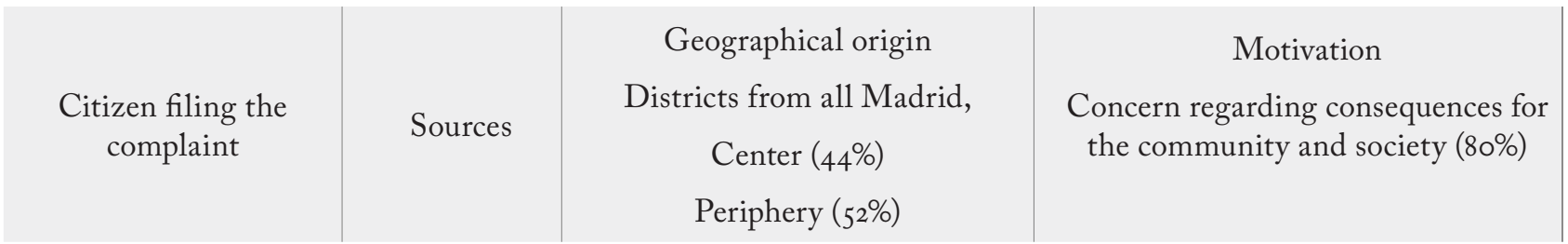

Source: Prepared by the authors.

solution or proposal offered and, finally, response of the institution.

It is noteworthy that complaints are concentrated on the issues of administration (29\%), followed by lack of cleanliness (28\%), and treatment given to waste, which accounts to $17 \%$ of cases. Consequences are identified that mainly affect the community (80\%). People assign the type of services delivered (56\%) as responsible for environmental conflicts. In the same files, people suggest solutions to the problems, mainly aimed at environmental administration issues such as: improving the quality of services (39\%), conducting educational campaigns ( $15 \%)$, improving control systems and current regulations (I4\%), and finally, Improving the environmental administration of the institution (пг\%). The environmental conflicts, are then focused on the quality and type of services received (39\%), followed by issues of hygiene on public roads ( $16 \%)$, the waste treatment system applied (II\%) and conflicts generated by affecting the aesthetics of places (го\%).

The responses given by the municipality to peopless complaints are categorized as follows: "Promises to improve the services delivered" (29\%). "Not providing a solution to the complaint" (28\%). There are also cases that are fall within the category "The problem does not exist at the time of inspection" (2r\%). Therefore, administration rarely solve the problems reported.

Finally, the analyzes carried out on the contents delivered by the people in the complaint files also allowed for the elaboration of characteristic profiles for the type of situations faced by people. Six differentiated profiles were identified:

Profile I. Formed by complaints related to suggestions and complaints related to the services provided by the municipality in matters of hygiene and safety in public spaces (253 cases).

Profile 2. Group with the largest number of grouped complaints, consisting of 303 suggestions and complaints, related to quality issues in the services responsible for hygiene, but there is also a significant concern regarding the aesthetics of the place for the presentation of complaints (I6\%). It also includes problems related to the use of water for street cleaning in public spaces and for recreation.

Profile 3. Constituted by only 20 problems, it is a very compact group that still attracts attention, because it is mostly made up of complaints regarding concerns about the aesthetics of places. They relate to the negative impact living in an environment considered unpleasant has on people for being visually overloaded, dirty or neglected (37\%).

Profile 4 . Formed by 84 incidents, which correspond to suggestions and complaints related to the type of use of public spaces (3r\%), secondly, there is evident concern here regarding the quality of services (I8\%) and almost at a same level the concern for the aesthetics of the places appears again ( $17 \%)$, the problems are attributed to bad municipal administration.

Profile 5. Formed by 249 incidents, grouped around inconvenience for the services received (47\%), the waste collection system implemented (I9\%). A new type of problem arises here, which links environmental conflicts to issues of inequality between citizens (8\%). This indicates that in this profile there is a feeling of discriminatory treatment by the municipality towards people. The problems would not be addressed with the same criteria and measures if the incidence occurs at a different place, therefore characteristics of the socio-economic context from which the complaint is made are an important influence.

Profile 6. This last profile consists of 79 issues, with files that request information or make suggestions to the municipality. No complaints were filed. They are suggestions for administration; improving the services received (39\%), suggestions related to waste management issues (34\%) and to improve the use of public spaces (13\%). The explanations for these conflicts were the little care given to public roads by the municipality and the 
systems implemented for the collection of waste and distribution of furniture.

Stage 3. Dialog with citizens.

These results are the product of the moment in which group and individual interviews are conducted, as well as voluntary online surveys. It aims at having direct contact with the users of public spaces who denounce environmental conflicts.

Members of environmental organizations, neighbors, officials and university students who had submitted complaints participated on this stage. An open coding of the group and individual interviews was carried out. There are five categories resulting from the codification of citizen discourses: Reasons for complaints, origin of environmental problems, proposals for action-solution, responsibilities for environmental problems and evaluation of the administration. Two great hypotheses appear from the application of this step of the grounded theory.

The axial coding of the categories yields links between some of them; Origin and types of environmental problems; Reasons for complaints and Responsibilities for environmental problems. Relationships given by everyday problems are observed, generally associated to waste thrown in public spaces, which in turn generates a set of types of problems that participants identify as evident in their daily life, given that they usually perceive them (easily) and in the same way, they affect them directly in their relationship with the immediate environment (e.g. dog waste).

Thus, a first Hypothesis arises, derived from axial coding, which shows that; The obvious problems (such as those derived from the possession of dogs in the city) become an environmental conflict that worries the inhabitants of the city, which generates complaints on a permanent basis. Therefore, the existence of easily perceived everyday environmental problems favors the identification and complaints due to environmental conflicts (that are evident). But this does not exclude the fact that people identify and express concern about other global environmental issues.

Just as there is a relationship between the origin of the problems and the types of environmental problems, there is also a link between the reasons for complaints and environmental responsibilities. In this case, this link is mainly given by complaints associated with the presence of vehicles or waste containers occupying public spaces. A situation that is perceived as a consequence of the lack of a responsible actor or authority who enforces the norms regulating this conflict, which has an impact on the use of places that are expected to be free for the use of all the community. In this sense, the responsibilities of environmental problems, and specifically of these types of problems in public spaces, would fall on the public administration, responsible for administration and management, which would not be fulfilling its role effectively according to citizen perception.

Summarizing, relationships between categories emerge during axial coding. Consequently, the Second Hypothesis arises: The obvious environmental problems tighten the relationship between citizens and the authorities that administer these spaces. Precisely, it is the relationship between the presence of waste in public spaces and the discomfort that it generates in citizens what would cause tension between the citizen and the public authority. This as a result of the perception that the authority does not exercise its enforcing role as expected. Finally, these elements will be theorized in the discussion of the results.

During this last stage of contact with people, a virtual survey was also applied, with both open and closed questions, via email. The survey was answered by 63 participants of the group interviews. Identification data was requested (membership in an organization, activity or profession, area of studies and place of residence). They are presented with a series of five open questions to confirm whether people have submitted complaints and the subject relative to their submitted complaints. The following questions aimed at knowing: Environmental problems that people recognize as more important in the global; what people should do to try to solve them; what actions or activities can be implemented to take care of the environment; the barriers participants identify to carry out responsible ecological behaviors were inquired, and finally, how people can be helped to conduct responsible behaviors in relation to the environment. In this section respondents are asked to assign importance or priority to each of 22 statements offered. These were collected using a Likert scale of four response categories, with the following options: It does not matter (value I), It has little importance (value 2), Important (3), Very important (4). A factorial analysis is performed for the analysis of these data, of an exploratory nature, 
latent factors were extracted through the Principal Components Method. It is possible to perform this type of analysis since the number of variables included is greater than I2. The number of factors selected corresponds to those that obtained eigenvalues greater than one. Subsequently, a Varimax rotation of the factors was performed, through a strong or weak association between factors and questions (Hair et al., 1999). The KMO statistic was 0.64 , which warrants that this type of analysis. Bartlettss test was significant, indicating that there was a correlation between the 12 items presented. Finally, four factors were selected (with eigenvalue greater than one), which explained $70 \%$ of the variability, statistically significant data.

The results allowed to organize the sample in distinctive profiles, which would determine whether or not a complaint was filed according to the characteristics of the group of belonging. It is interesting to note how people assign different priorities to the factors identified for environmental complaint behavior. The identified factors were: The Environmental Commitment, expressed in the concern or discomfort when an environmental conflict is perceived (which seems to be the most relevant factor for those who are volunteers or workers of environmental NGOs). The Trust factor in that the institution will actually accept the complaint and in the citizen's capacity to file the complaint is also a shared and decisive element for the presentation of complaints for groups of volunteers and team members of environmental organizations. However, the factor knowing the procedures that guide the submission of a complaint and the consideration they give to the possibility of succeeding in this process present differences between them. In this case, the volunteers do not consider it important if the complaint is accepted or not, but rather the action of carrying out the complaint has a value in its own. Therefore, if the conflict exists, they will complain anyway to the corresponding instances. On the other hand, the technicians and professionals in charge of the work teams in environmental social movements do not assign value to knowing the procedure for making the complaint. They assign the greatest importance to the probability that this act of complaining might be successful or productive.

Finally, the group that presented the greatest comparative differences with the other two is the one formed by the members of the University Ecocampus. A group that we can characterize as the most heterogeneous, and less technical or aware of the subject. Students, administration and academic staff, all of them affected by issues related to care for the environment, but not as a central activity in their daily lives, participated in this group. We can consider it as the closest group, according to the characteristics, to common people, to the citizens who complain, for whom the pro-environmental commitment is an option that seems to arise at the moment of perceiving a conflict in their daily activities which pushes them to file a complaint. For this group, trust in that the complaint may have a positive result would be the most important element to consider when filing a complaint relative to environmental issues with the corresponding agencies.

Thus, it can be concluded that the determinants will differ in relation to who files the complaint. The environmental commitment associated with pro-environmental values (internal elements to people) is the engine that motivates the actions of the ones that are most involved or aware of the environmental cause. The complaint would be a manifestation of their commitment, regardless of the difficulties they might face after filing the complaint. They aim at making an impact on the administration and the authorities so they solve the problem. On the other hand, for those who show lower or circumstantial commitment, the determining factors will be contextual and institutional, such as the possibilities of reception or success when filing a complaint.

Taking these elements into account, it is possible to think that complaint behavior on environmental issues presents an important political component in those who already have a positive environmental concern or attitude. For the rest of the population, from a circumstantial happening to daily experience, the complaint can only seek to resolve a specific conflict, since it affects them personally or their closest community.

\section{DISCUSSION AND CONCLUSIÓN}

Regarding the general objective of this research, which was to understand and characterize the situations and the sense given to behavior in environmental matters by people, we conclude that the presentation of complaints before a local municipality seeks to bring satisfaction to welfare and comfort needs, however, for the most part, the complaint is also filed as an attempt to solve an 
environmental problem that causes concern since it affects the community.

Within an environmental complaint (CQA), expectations regarding the role of people in todayss society can be observed, an active role in caring for the quality of life they believe they deserve. Complaints arise as a form of exercising this new citizen role, confident in their right to demand the authorities to carry out their function of ensuring everybodyss welfare, enforcing laws and protecting life, which is a function assigned to them by citizen mandate. These expectations towards the elected authority, could be an example of the manifestation of how citizens expect representative democracy to be exercised, expressed in peopless demands to the ones they have elected.

It appears that filing complaints on environmental issues is an example of exercising popular sovereignty, or governance. Citizens make use of a technical instrument (SyR file) that the authority itself puts at their disposal to identify situations or conflicts that affect their daily lives, when these conflicts or situations seem to become a hazard or an abuse to their acquired rights.

The environmental complaint thus seems to be a natural effect and consequence of the use of a space for social participation, which has been built for the people by the same municipality. A space which will be very efficient if it is well managed, if it is considered an opportunity to promote communication with citizens, transparency, and therefore, local democracy.

People value public spaces in the city, particularly those dedicated to green areas, for resting, practicing sports and leisure (squares, parks and streets). They are considered spaces belonging to all, so they must be available and in good hygienic and aesthetic conditions for public use. The inability to enjoy these spaces either due to being used for other purposes (e.g. garbage containers, vehicles, or terraces) or due to carelessness and lack of maintenance, causes citizens concern and discomfort, a situation that ends in complaints when this situation is perceived as disrespectful of citizen rights when the conflict is not solved. The responsibility for the problem is attributed to poor administration and poor quality of services delivered by the authority, that ends up being perceived as inefficient, incoherent and negligent, since it does not enforce the norms and does not exercise its role of control over the ones who violate them.
Although concerns and filing complaints are mainly focused on problems that are evident and those that affect peopless daily lives due to the direct impact they facts have on the lives of citizens (easily perceivable), global problems, despite less evident for people, are still present or recognized.

The perception of the role that people assign themselves within their cities has changed in relation to the care of the environment and also in their relationship with the local political authority. With the environmental complaint, people are expressing concern regarding the poor state of their environment, since they consider living in an environment free of pollution and risk a citizen's right. They express complaints as an inconvenience, trusting the public administration in solving and taking care of these conflicts. It is also interesting to note at this point that the responsibility is not only directed to the administration, also to companies, to the family, to other citizens, to society in general. This seems to indicate that people make both criticism and self-criticism regarding responsibilities in environmental deterioration, which could be a facilitator when designing an environmental intervention (McKenzieMohr, 20oob), which was also mentioned by E. Wiesenfeld (200I, 20I3).

The experts consulted conclude that the environmental complaint is a deliberate behavior, therefore, intentional and voluntary. Among their characteristics they identify what constitutes a behavior:

- Actively demanding, defined as an action of protest which can be collective or individual.

- It will also be specific and situational.

- It can also be virtual (cyberactivism) or direct (filing complaints or manifesting them publicly).

- It is finalist, since it is aimed at achieving an end in favor of the environment and placing issues relative to preservation of the environment and protection of the quality of citizens' lives on the public agenda and municipal administration.

- It therefore has the objective to show rejection to decisions taken at other levels that are considered harmful to the environment in the city.

- It is understood that the behavior is product of the impact caused on the person or social group, a fact that visually generates conflict or the perception of insecurity or risk.

- It arises from unfulfilled expectations; this is the case of the evaluation of the state of the environment and the role that the public administration must carry out in these cases. 
It seems important to emphasize that arising from the phenomenon of the complaint for environmental issues, the possibility of asking about the potential of the complaint as an opportunity to improve is derived, also as an element of education, seeking not only the avoidance of environmental damage, but also the strengthening of the relationship between citizen and the administration. The complaint mobilizes people, as a shared vision, through seeing the "complaints» of others (the ones that are similar to mine). All of which could become an important and powerful input of local social organization in search of solving common and obvious concrete problems, whose impact is not only local, but also correlates socially and globally.

For the public administration, the issue should not only be about attempting to have spaces for the reception of complaints, but also about the way in which the complaint is "solved". In addition, in its management it is key to favor its integration, not only in a global management, but to favor its social representation in local-global fashion, which will depend on the way the administration and also the rest of the participants act (companies, citizenship, associations, etc.). A participatory environmental administration, in which the roles between representatives and representatives are respected and in which, in addition to demanding responsibility and from accountability, the political action is rethought as favoring empowerment and the sense of community (Sánchez-Vidal , 20or; Rappaport, 1987; Zimmerman, 2000). An administration in which urban environmental problems are solved, and deliberative democracy is strengthened.

The research contributes by delivering elements that allow to deepen a little more in the understanding of the complexity that has been produced in the relation between citizens and public authority. Particularly with the implementation of democracy, legislative changes and the appearance of associated instruments that support governance, especially on environmental issues happening in the European Union.

The use of the mixed method allows for the analysis of varied data which, under the guidance of the Grounded Theory principles, opened possibilities of analysis and access to different voices, something we consider to be a success, since it favors understanding from different perspectives towards the phenomenon of environmental complaint.
Generating knowledge from beliefs, reflections and implicit theories of people who actually experience the problem, together with being able to put them in contrast with what is stated by the scientific theories and technical procedures related to the specific situations harbors the complexity of the phenomenon under study, which demands a multifactorial approach.

Contributions to management. Suggestions for municipal administration.

Information derived from the complaints provides indexes of users' dissatisfaction linked mainly to administration applied to addressing environmental problems. The analysis of the complaints and the type of response the institution gives are fundamental for the generation and development of quality strategies. These are relevant elements when organizational performance and efficiency are evaluated, also to guarantee the user or customer satisfaction. The information provided in the complaints allows institutions to ensure the coherence in the operational processes and support for environmental management, as well as fulfilling the commitment of incorporating citizen participation in the administration.

Environmental complaints are an excellent tool for the evaluation of the situation or state of the built urban environment. It allows for the definition of more appropriate strategies, a sectorization of the intervention, differentiation between the different need needs and the distribution of resources resources in a fair and balanced way according to "local realities".

Strengthening the mechanisms and instruments that favor citizen participation allows to improve administration, making it both more efficient and relevant. Considering and incorporating the suggestions that come from everyday life, allows a less technical and more real administration. All of which ultimately means saving resources and improving environment care in the city. This is accomplished as long as an adequate analysis and treatment of complaints and suggestions is performed, and the data is properly incorporated into the improvement process of the municipal administration.

The administration process must contemplate the appropriate response to who files the complaint, describing the evaluation and the way their complaint was addressed. Particularly, the solution implemented must be included in the response. The intervention design must consider 
a prudent follow-up period of the solution for its evaluation. Complaints and suggestions can improve local ordinances and laws for environmental protection, this is an exercise that would provide greater value and transparency to the authorities in their administration in the urban environment.

\section{REFERENCES}

Aguilar Villanueva, Luis F. (2006), Gobernanza y gestión pública, México, Fondo de Cultura Económica.

Alfie M., Cohen, L., Díaz, A., Castañeda, R. (2011) "Una ventana de oportunidad: la gobernanza ambiental, nuevo instrumento de política" Consultado el 03 de marzo del 2014: https://bit.ly/2PBvMF8

Alli Aranguren, Juan Cruz.(2013). Las previsiones de la Ley $5 / 2006$, de 2 de mayo, de ordenación del territorio y urbanismo, de la Comunidad Autónoma de La Rioja sobre patrimonios públicos de suelo, su constitución y gestión, y derecho de tanteo y retracto. Revista de derecho urbanístico y medio ambiente, ISSN 1139-4978, Año no 47, № 283, 2013, págs. 77-96.

Bäckstrand, K. y et. al. (2010). "The Promise of New Modes of Environmental Governance" en Environmental Politics and Deliberative Democracy. Examining the Promise of New Modes of Governance. Cheltenham, Edward Elgar (eds).

Bamberg, S., \& Moser, G. (2007). Twenty years after Hines, Hungerford and Tomera: A new meta-analysis of psychosocial determinants of proenvironmental behaviour. Journal of Environmental Psychology, 27, 14-25.

Bearden, W.O. y Oliver, R.L. (1985). "The role of public and private complaining in satisfaction with problem resolution". Journal of Consumer Affairs, Vol. 19 (Invierno), pgs. 222-240.

Beck, U. (1998). World Risk Society. Cambridge, Polity Press.

Biermann, F. et. al. (2009). "Global Environmental Governance and the International

Organizations. Setting the Stage" en International Organizations in Global Environmental Governance. Abingdon, Routledge.

Blumer, H. (1969). Symbolic Interactionism. Perspective and Method. Berkeley and Los Angeles, California: University of California Press. Creswell, J.W. (2013). Research Design: Qualitative, Quantitative and Mixed Methods Approaches. 273 pp. SAGE. ISBN, 1452226105, 9781452226101

Bonet, m., Dimasso, a., Duque, i., écija, m. \& pol, e. (2006). El papel de la participación ciudadana en el planeamiento urbano: una propuesta técnica. EnJ. Corraliza, J. Berenguer\&R. Martín (Eds.), Medioambiente, Bienestar Humano y Responsabilidad Ecológica. IX congreso de Psicología Ambiental (pp.198-203). Madrid: Editorial Resma y Fundación General de la UAM.

Broadbridge, A. y Marshall, J. (1995). "Consumer complaint behaviour: the case of electrical goods". International Journal of Retail \& Distribution Management, Vol. 23, no 9, pgs. 8-24. Cornwell, T. B., Bligh, A. D. y Babakus, E. (1991). “Complaint Behavior of Mexican-American Consumers to a Third-Party Agency", Journal of Consumer Affairs, Vol. 25(1), pp. 1-18.

Clark, M. E. (1995). Changes in Euro-American Values Needed for Sustainability. Journal of Social Issues, 51(4), 63-82
Creswell, J.W. (2013). Research Design: Qualitative, Quantitative and Mixed Methods Approaches. 273 pp. SAGE. ISBN, 1452226105, 9781452226101

Crie, D. (2003). "Consumer's Complaint Behavior. Taxonomy, Typology and Determinants: Towards a Unified Ontology", Journal of Database Marketing \& Customer Strategy Management, Vol. 11(1), pp. 60-66.

Crotty, M. (2003). The foundations of social research: Meaning and perspective in the research process. Thousand Oaks, CA: Sage.

Fornell, C. y Wernerfelt, B. (1987). "Defensive marketing strategy by consumer complaint management: a theoretical analysis". Journal of Marketing Research, Vol. 24 (Noviembre), pgs. 337-346.

González Rey, F. L. (2000). Investigación cualitativa en psicología: Rumbos y desafíos. México. International Thomson. Gardner, G. T. \& Stern, P. C. (1996). Environmental problems and human behavior. Boston: Allyn and Bacon.

Heung, V. C. S. y Lam, T. (2003). "Customer Complaint Behavior Towards Hotel Restaurant Services", International Journal of Contemporary Hospitality Management, Vol. 15(5), pp. 283-289

Hernández, B. \& Suárez, E. (2006a). Alcance del Ambientalismo. Análisis de la relación entre intención y acción en el ámbito del comportamiento proambiental. En M. Amerigo \& B. Cortez (Comps.), Entre la persona y el entorno. Intersticios para la investigación medioambiental (pp. 59-77). Tenerife: Editorial Resma, S.L.

Hines, J. M., Hungerford, H. R., \& Tomera, A. N. (1986/87). Analysis and synthesis of research on responsible environmental behavior: A meta-analysis. Journal of Environmental Education, 18, 1-8.

Khan, U. (Ed.), (1999). Participation beyond the ballot box: European case studies in state-citizen political dialogue. London: UCL Press.

Liu, R.R. (1999). "Consumer social values and complaint behaviors”. Enhancing

Knowledge Development in Marketing. Brown, S. y Sudhashan, D. (eds.), American Marketing Association, Chicago, IL, Vol. 10, pgs. 279-287.

. y Mcclure, P. (2001). “Recognizing cross-cultural differences in consumer complaint behavior and intentions: an empirical examination”. Journal of Consumer Marketing, Vol. 18, no 1, pgs. 54-74.

Lovelock, C, y Wirtz, J. 2007. Services MarketingPeople, Technology, Strategy. Pearson Prentice Hall. S i x th e d i tion

McAlister, D.T. and R.C. Erffmeyer (2003), "A content analysis of outcomes and responsibilities for consumer complaints to third-party organizations," Journal of Business Research, 56, 341-351.

McKenzie-Mohr, D. (2000a). Fostering sustainable behavior through community-based social marketing. American Psychologist, 55(5), 531-537. Retrieved from www.scopus.com

(2000b). Promoting sustainable behavior: An introduction to community-based social marketing. Journal of Social Issues, 56(3), 543-554. Retrieved from www.scopus.com Manzo, L. C. \& Weinstein, N. D. (1987). Behavioral commitment to environmentalprotection. A study of active 
and nonactive members of the Sierra Club. Environment and Behavior, 19(6), 673-694.

Mattila, A. (1999), "The role of culture and purchase motivation in service encounter evaluations," The Journal of Services Marketing, 13 (4/5), 376-390.

and P.G. Patterson (2004), "Service Recovery and Fairness Perceptions in Collectivist and Individualist Contexts," Journal of Service Research, 6 (4), 336-346.

Meadowcroft, J. (1996). The Liberal Political Tradition. Contemporary Reappraisals. Canada, Carlton University.

Merleau-Ponty, M. (1962). Phenomenology of perception. (C. Smith, Trad.) New York: Humanities Press.

Milbrath, L. W. (1995). Psychological, Cultural, and Informational Barriers to Sustainability. Journal of Social Issues, 51 (4), 101-120.

Moliner Velázquez, B. (2004): «La formación de la satisfacción/ insatisfacción del consumidor y del comportamiento de queja: aplicación al ámbito de los restaurantes», Tesis Doctoral dirigida por la Dra. Irene Gil Saura y la Dra. Gloria Berenguer Contrí, Universidad de Valencia.

(2007). Determinantes del Comportamiento de Queja del consumidor: Una Revisión. Estudios Sobre Consumo 80, pp. 29-47.

(2008). Análisis del comportamiento de queja del consumidor: Una investigación en el contexto de queja de restaurantes. Investigaciones Europeas de Dirección de la Economía y Empresa. Vol 14, No 2, pp. 13- 33

Moreno Pino, Peña Escobio, Tapia Claro y Sánchez Zaldívar. (2009). "¿Cómo gestionar la calidad en el proceso de manejo de quejas?” en Contribuciones a la Economía, agosto 2009 en http://www.eumed.net/ce/2009a/

Moyer, M. (1984). "Characteristics of consumer complaints: implications for marketing and public policy”. Journal of Public Policy and Marketing, Vol. 3, pgs. 67-84.

Ohmae, K. (1995). The End of the Nation-State: The Rise of Regional Economics, New York, Free Press.

Oliver, R.L. (1987). "An investigation of the interrelationship between consumer (dis)satisfaction and complaints reports". Advances in Consumer Research, Vol. 14, pgs. 218-222.

Palavecinos M., Martín R., Díaz Ma J., Piñeiro C; Benayas J; Alonso L.E. \& Jimenez, A (2008). "Comportamiento proambiental: Estudio del comportamiento de queja ciudadana. Implementación de un sistema participativo de gestión ambiental en Madrid.” Revista de Psicología Social. España. 23 (2). Pp. $243-257$

Pont Vidal, J. (2004). La ciudadanía se moviliza. Los movimientos sociales y la globalización en España. Barcelona: Flor del viento ediciones.

Rappaport, J. (1987). Terms of empowerment/exemplars of prevention: toward a theory for community psychology. American Journal of Community Psychology. , 15, 121 -144

Richins, M.L. (1983a). "Negative word-of-mouth by dissatisfied consumers: a pilot study". Journal of Marketing, Vol. 47 (Invierno), pgs. 68-78.

Sánchez -Vidal, A. (2001). Medida y estructura interna del sentimiento de comunidad: un estudio empírico. Revista de Psicología Social. 16 (2), 157-175

Singh, J. y Howell, R.D. (1985). "Consumer complaining 506 behavior: a review and prospectus”. Consumer Satisfaction,
Dissatisfaction and Complaining Behavior. Hunt, H.K. y Day, R.L. (eds.), Bloomington, IN: Indiana University, pgs. 59-66.

(1988). Consumer complaint intentions and behavior: definitional and taxonomical issues. Journal of Marketing, 52, 93-107.

(1990a). "Voice, exit and negative word-of-mouth behaviors: an investigation across three service categories". Journal of the Academy of Marketing Science, Vol. 18, $\mathrm{n}^{\circ}$ 1,pgs. 1-15.

y Wilkes, R.E. (1996). "When consumers complain: a path analysis of the key antecedents of complaint response estimates". Journal of the Academy of Marketing Science, Vol. 24, no 4, pgs. 350-365.

y Wilkes, R.E. (1991). "A theoretical framework for modeling consumers' response to marketplace dissatisfaction”. Journal of Consumer Satisfaction, Dissatisfaction and Complaining Behavior, Vol. 4, pgs. 1-12

Stake R. E. 2005. Investigación con estudios de casos Ediciones Morata SRL. 3a ed., Traducción: Roc Filella Colección: Manuales Madrid

Stern and G. T. Gardner, "Psychological Research and Energy Policy," American Psychologist 36, no. 4 (1981): 329-42; G. T. Gardner and P. C. Stern, Environmental Problems and Human Behavior (Boston, MA: Allyn and Bacon, 1996), 253-76; and G. T. Gardner and P. C. Stern, Environmental Problems and Human Behavior, 2nd Edition (Boston, MA: Pearson Custom Publishing, 2002), 253-76.

Stern, P. (2000). Toward a Coherent Theory of Environmentally Significant Behavior. Journal of Social Issues, 56 (3), 407- 424.

, Dietz, T., Abel, T., Guagnano, G. A. \& Kalof, L. (1995). Values, beliefs and proenvironmental action: Attitude formation toward emergent attitude objects. Journal of Applied Social Psychology, 25, 1611-1636.

, Dietz, T., Abel, T., Guagnano, G. A. \& Kalof, L. (1999). A value-belief-norm theory of support for social movements: The case of environmentalism. Human Ecology Review, 6, 81-97.

\& Oskamp, S. (1987). Managing scarce environmental resources. In D.

Stokols, D. (1990). Instrumental and spiritual views of peopleenvironment relations. American Psychologist, 45, 641-646.

Suárez, E. (1996). La participación ambiental como conducta altruista. En Ciudad y medio ambiente desde la experiencia humana. Mongrafies Psico/Socio/Ambientals, 10 (pp. 289294). Barcelona, España.: Universitat de Barcelona.

(2006). Problemas ambientales y soluciones conductuales. En J.I. Aragones y M. Amerigo (coords.) Psicologia Ambiental (pp. 331-355). Madrid Pirámide. 2da Edición.

Tanner, C. (1999). Constraints on environmental behaviour. Journal of Environmental Psychology, 19, 145-157.

Wiesenfeld, E., \& Sánchez, E. (2013). Community sustainability: Orientations and implications from environmental community psychology. En V.Corral-Verdugo, C. H. Garcia-Cadena \& M. Frias-Armenta. Psychological approaches to sustainability: Current trends in theory, research and applications (317-336). New York: Nova Science Publishers, Inc. 
Wiesenfeld, E. (2001) La problemática ambiental desde la perspectiva psicosocial comuntaria: Hacia una psicologia ambiental del cambio. Medio ambiente y Comportamiento Humano, 2(1), 1-19

Westbrook, R. A. (1987): «Product consumption-based affective responses and postpurchase processes», Journal of Marketing Research, vol. 24 (agosto), pp. 258-270.

White, L. (1967). The historical roots of our ecologic crisis. Science, 155, 1203-1207.

White, L. (1974). The historical roots of our ecologic crisis. In J. H. Sims \& D. D.

Yin Robert K., 1984. Investigación Sobre Estudio De Casos Diseño y Métodos. Segunda Edición. Applied Social Research Methods Series. Volume 5 SAGE Editions. International Educational and Professional Publisher Thousand Oaks London New Delhi.

Zeithaml, V.A., M.J. Bitner and D.D. Gremler (2006), Services Marketing: Integrating Customer Focus Across the Firm, New York: McGraw-Hill Irwin.

Zimmerman, M. A. (2000). Empowerment theory: psychological, organizational, and community level of analysis. En J. Rappaport \& E. Seidman, Handbook of Community Psychology (43-63).New York: Kluwer Academic. 